УДК 342.9:343.148.7:615.2

КУЗЬМІНА Т.О., ЧУРСІНА Л.А., БЕРЕЗОВСЬКИЙ Ю.В. Херсонський національний технічний університет

\title{
АКТУАЛЬНІ ПИТАННЯ МИТНОГО КОНТРОЛЮ ТА ЕКСПЕРТИЗИ ЛІКАРСЬКИХ ЗАСОБІВ, ЩО ВВОЗЯТЬСЯ НА ТЕРИТОРІЮ УКРАЇНИ
}

\author{
KUZMINA T.O., CHURSINA L.A., BEREZOVSKY YU.V. \\ Kherson National Technical University
}

\section{CURRENT ISSUES OF CUSTOMS CONTROL AND EXPERTISE OF MEDICINAL PRODUCTS INTRODUCED TO THE TERRITORY OF UKRAINE}

\author{
КУЗЬМИНА Т.О., ЧУРСИНА Л.А., БЕРЕЗОВСКИЙ Ю.В. \\ Херсонский национальный технический университет
}

\section{АКТУАЛЬНЫЕ ВОПРОСЫ ТАМОЖЕННОГО КОНТРОЛЯ И ЭКСПЕРТИЗЫ ЛЕКАРСТВЕННІХ ПРЕПАРАТОВ, КОТОРЫЕ ВВОЗЯТСЯ НА ТЕРРИТОРИЮ УКРАИНЫ}

\section{https://doi.org/10.36910/6775-2310-5283-2020-13-11}

Мета. Дослідження особливостей проведення митної експертизи лікарських засобів як складової митного контролю та митного оформлення при переміщенні изього виду товарів через митний кордон Украӥни.

Методи дослідження. Під час дослідження використано загальнонаукові та спечіальні методи наукового пізнання: аналізу, синтезу, компаративно-правовий, системноструктурний, статистичний.

Результати. Імпорт лікарських засобів в Украӥну обмежений. Він може здійснюватися лише за наявності ліцензї на такий імпорт. При чому імпортовані можуть бути лише лікарські засоби, зареєстровані в Украӥні, крім цฺього, необхідно, щцоб вони пройшли сертифікацію якості у виробника.

3 метою розвитку інноваціийних технологій запроваджено диференційований контроль якості лікарських засобів, щзо ввозяться для реалізації, та контроль якості препаратів, щзо ввозяться для інших цілей. Наприклад, для проведення клінічних випробувань, реєстрації, експонування на виставках без права реалізації, індивідуального використання громадянами та в разі, катастроф $i$ епідемій.В роботі розглянуто продукцію 4-х іноземних фірм-виробників, лікарські засоби яких, широко представлені на фармацевтичному ринку України: KRKA Group, Словенія; Bayer, Biologische Heilmittel Heel GmbH, Німеччина; JANSSEN-CILAG S.p.A. JOHNSON \& JOHNSON, Iталія. $3 а$ 
результатами проведених товарознавчих досліджень виявлено, щцо всі досліджувані лікарські засоби вищенаведених фірм-виробників пройшли необхідні етапи щзодо імпортованих лікарських засобів: лічензування, реєстрацію в Україні, сертифікацію якості у виробника та входять до переліку зареєстрованих лікарських засобів Украӥни. Також визначено правильність оформлення супровідної документації; проведено аналіз асортиментної приналежності замовленого товару; встановлено відповідність товару класу, групі, виду або різновиду, вказаному в супровідній документації; проведено ідентифікацію товару за показниками «Опис», «Маркування», «Пакування».

Розглянуто форми митного контролю лікарських засобів, щзо перемішуються через митний кордон Украӥни та побудовано класифікацію видів їх митного контролю.

Наукова новизна. Комплексне дослідження сучасних проблем митного контролю та експертизи імпортованих лікарських засобів: побудовано класифікацію видів митного контролю лікарських засобів, запропоновано мінімізацію суб 'єктивних чинників прийняття рішення.

Практична значимість. Результати можна використовувати у науково-дослідній роботі для подальшого вивчення особливостей організаиї митного регулювання зовнішньоекономічної діяльності; у навчальному процесі при підготовці курсу лекцій $з$ товарознавства у митній справі, митного контролю та експертизи товарів.

Ключові слова: лікарські засоби, товар, митний кордон, митна експертиза, кордон, митний контроль, митне оформлення.

\section{Постановка проблеми у загальному вигляді і їі зв'язок з важливими} науковими та практичними завданнями. На сучасному етапі розвитку ринок лікарських засобів України вже тривалий час входить до найприбутковіших галузей економіки.

В Україні зареєстровано більше ніж 12 тисяч найменувань лікарських засобів. Майже $70 \%$ зареєстрованих лікарських засобів, що реалізуються в Україні, $є$ імпортованими, а лікарські засоби вітчизняного виробництва переважно виготовляються із субстанцій іноземного виробництва (3 імпортованої сировини) [1]. Також треба відзначити, що імпортні ліки домінують на фармацевтичному ринку і у вартісному вираженні.

За статистичними даними в останні 5 років Державною службою України 3 лікарських засобів і контролю за наркотиками (Держлікслужба) не допущено до споживача (знищено, утилізовано, повернуто постачальникам) близько 10 млн упаковок лікарських засобів неналежної якості із 2432 найменувань неякісних, фальсифікованих та незареєстрованих лікарських засобів на загальну суму близько 285 млн грн. Дерегуляція і, як наслідок, послаблення державного контролю у галузях, які стосуються безпеки життя та здоров'я громадян, призводять до негативних результатів. Наразі держава не може гарантувати споживачеві якість ліків. Тому питання митного регулювання 
діяльності із забезпечення та експертизи лікарських засобів, що переміщуються через митний кордон України $є$ актуальними 3 огляду на нинішню ситуацію на фармацевтичному ринку [2].

Аналіз останніх досліджень, у яких започатковано вирішення проблеми. У сучасних умовах порядок переміщення товарів і транспортних засобів через митний кордон України характеризується як дозвільний, і тому роль митних органів як контролюючих суб'єктів у цьому процесі постійно зростає. Порядок переміщення лікарських засобів через митний кордон України нерозривно пов'язаний зі здійсненням митними органами процедур митного контролю (статті 40, 45, 81, 86 МК України) [3]. У той же час останні здійснюються в порядку й на умовах, передбачених ст. 40 МК України, відповідно до якої всі товари (в тому числі й лікарські засоби) і транспортні засоби, що переміщуються через митний кордон, підлягають такому контролю.

Ввезення зареєстрованих та незареєстрованих лікарських засобів нормативно закріплено ст. 17 Закону «Про лікарські засоби» [4], а також наказом MO3 України «Порядок ввезення на територію України незареєстрованих лікарських засобів, стандартних зразків, реагентів» [5]. Зазначимо, що при переміщенні лікарських засобів, що містять наркотичні складники, існує інший порядок переміщення таких засобів через митний кордон.Основні завдання митного контролю, які зумовлені його загальною метою та відповідають встановленій державою компетенції митних органів, визначив Р.Б. Шишка. Вони полягають: у захисті економічних інтересів держави; у виявленні відповідності проведених митних дій та операцій чинному законодавству; у дотриманні фізичними та юридичними особами встановлених митних процедур і правил при переміщенні товарів через митний кордон України $[6,7]$.

Гаращук В.М. виділив основні функції митного контролю, такі як наповнення державної казни шляхом стягнення мита та інших митних платежів, захист зовнішніх та внутрішніх економічних інтересів держави, національного виробника, реалізація та забезпечення законності і дисципліни учасників митних правовідносин, попередження та припинення порушень митних правил, застосування правових санкцій щодо правопорушників, розробка й запровадження (разом 3 іншими компетентними органами) механізму зовнішньої та внутрішньої економічної політики [7].

Значного поширення набула проблема боротьби із незаконним ввезенням та вивезенням лікарських засобів (в тому числі фальсифікованих, неякісних, 
контрафактних тощо), яка стоїть перед більшістю країн світу. На сесії Всесвітньої митної організації (Україна $є$ ії членом) у докладі про лікарські засоби наведено, що переміщення та реалізація контрафактних і підроблених лікарських засобів набуває катастрофічного розмаху, оскільки на сьогодні вже йдеться про друге після наркотиків (якщо не перше) місце у незаконній світовій торгівлі. Торгівля фальсифікованими, контрафактними лікарськими засобами становить 10 \% світової торгівлі фармацевтичною продукцією на суму близько 45 мільярдів євро [8]. Щороку фальсифіковані лікарські засоби забирають близько 200 тисяч життів, у той час як на цих життях фальсифікатори заробляють близько 50 млрд доларів [9]. Рентабельність виготовлення та збуту 1 кг фармацевтичних підробок може досягати $2000 \%$. Для порівняння: при виготовленні 1 кг неочищеного героїну цей показник вдесятеро менший [9].

В умовах розбудови Української держави нагальним постає питання 3 недопущення ввезення неякісних, несертифікованих, заборонених до ввезення імпортних лікарських засобів, оскільки деякі недобросовісні суб'єкти зовнішньоекономічної діяльності при переміщенні лікарських засобів через державний кордон, на жаль, можуть приховувати характеристики справжнього хімічного складу переміщуваного товару. У таких випадках для ідентифікації зазначених лікарських засобів проводиться їх митна експертиза, яка відіграє важливу роль у сфері регулювання митних правовідносин як невід'ємна частина митного контролю та митного оформлення.

На сьогодні експертна діяльність набуває особливого значення, оскільки вибір курсу до Європейського Союзу потребує приведення існуючих методів контролю за порядком переміщення лікарських засобів через митний кордон України до загальноєвропейських стандартів.

Проблеми митного контролю та митної експертизи вивчалися багатьма вченими: В.Б. Авер'яновим,

А.П. Альохіним,

Д.М. Бахрахом, І.П. Голосніченко, Ю.М. Дьоміним, В.М. Гаращуком, Д.В. Приймаченко, В.К. Шкарупою, А.В. Мазуром, О.В. Поліщуком та ін. [10]. Проте митній експертизі лікарських засобів при їх переміщенні через державний кордон на сьогоднішній день приділяється замало уваги, що спричиняє виникнення низки спірних питань та збільшення тривалості й матеріальних затрат при проведенні митного контролю ліків.

Цілі статті. Мета роботи полягає у дослідженні особливостей проведення митної експертизи лікарських засобів як складової митного контролю та 
митного оформлення при переміщенні цього виду товарів через митний кордон України.

Об’єкт дослідження - система відносин, які виникають в процесі переміщення лікарських засобів через митний кордон України під час виконання митних формальностей.

Методи дослідження. Методологічною основою проведених досліджень обрано комплекс загальнонаукових та спеціальних методів наукового пізнання, об'єднаних системним підходом, що дозволило з'ясувати сутність досліджуваних явищ і процесів з урахуванням зв'язків, які між ними виникають. Так, методи аналізу і синтезу використано під час визначення особливостей правового регулювання митних режимів за законодавством України. Компаративно-правовий метод застосовувався при аналізі особливостей правового регулювання митних режимів в Україні. Використання системноструктурного методу дозволило побудувати класифікацію митних режимів. Статистичний метод - при аналізі статистики щодо обігу лікарських засобів, при узагальненні результатів діяльності державних регулюючих органів, які здійснюють митний контроль та контроль за обігом лікарських засобів.

Виклад основного матеріалу дослідження 3 повним обгрунтуванням отриманих наукових результатів. Правовідносини, пов'язані зі створенням, реєстрацією, виробництвом, контролем якості та реалізацією лікарських засобів, права та обов'язки підприємств, установ, організацій і громадян, а також повноваження у цій сфері органів виконавчої влади і посадових осіб визначені та регулюються Законом України «Про лікарські засоби» (далі Закон). Законодавство про лікарські засоби складається із Закону та інших актів законодавства, прийнятих відповідно до нього. Відповідно до Положення про Державну службу України з лікарських засобів та контролю за наркотиками, затвердженого постановою Кабінету Міністрів України від 12 серпня 2015 р. № 647, центральним органом виконавчої влади, який реалізує державну політику у сферах контролю якості та безпеки лікарських засобів, $\epsilon$ Державна служба України з лікарських засобів та контролю за наркотиками (Держлікслужба).

Відповідно до Закону, лікарський засіб - це будь-яка речовина або комбінація речовин (одного або декількох активних фармацевтичних інгредієнтів та допоміжних речовин), що має властивості та призначена для лікування або профілактики захворювань у людей, чи будь-яка речовина або комбінація речовин (одного або декількох активних фармацевтичних інгредієнтів та допоміжних речовин), яка може бути призначена для 
запобігання вагітності, відновлення, корекції чи зміни фізіологічних функцій у людини шляхом здійснення фармакологічної, імунологічної або метаболічної дії або для встановлення медичного діагнозу.

До лікарських засобів належать: активні фармацевтичні інгредієнти; продукція «in bulk» (продукція «in bulk» - будь-який лікарський засіб, призначений для виробництва готового лікарського засобу, який пройшов усі стадії технологічного процесу, крім стадії фасування та/або кінцевого пакування і маркування); готові лікарські засоби (лікарські препарати, ліки, медикаменти); гомеопатичні засоби; засоби, які використовуються для виявлення збудників хвороб, а також боротьби із збудниками хвороб або паразитами; лікарські косметичні засоби та лікарські домішки до харчових продуктів.

Кабінет Міністрів України зазначив. що імпорт лікарських засобів в Україну обмежений. Він може здійснюватися лише за наявності ліцензії на такий імпорт. При чому імпортовані можуть бути лише лікарські засоби, зареєстровані в Україні, крім цього, необхідно, щоб вони пройшли сертифікацію якості у виробника. Тобто для подолання обмеження необхідно три документи, які відіграють роль дозвільних: ліцензія, свідоцтво й сертифікат якості.

В роботі розглянуто продукцію 4-х іноземних фірм-виробників, лікарські засоби яких, широко представлені на фармацевтичному ринку України: KRKA Group - 11 засобів (одна 3 провідних компаній-виробників генеричних лікарських засобів у світі, Словенія), компанія Bayer - 11 препаратів (інноваційна компанія 3 давньою традицією дослідницьких розробок у сфері охорони здоров'я, Німеччина), Biologische Heilmittel Heel GmbH - 11 препаратів (один 3 найбільших в світі виробників гомеопатичних засобів, Німеччина), компанія JANSSEN-CILAG S.p.A. JOHNSON \& JOHNSON - 8 засобів ( $є$ одним 3 найважливіших постачальників лікарських засобів на світовому фармацевтичному ринку, Італія), подано їх стислу товарознавчу характеристику, особливості товарознавчого аналізу медичних та фармацевтичних товарів. За результатами проведених товарознавчих досліджень можна стверджувати, що всі досліджувані лікарські засоби вищенаведених фірм-виробників пройшли необхідні етапи щодо імпортованих лікарських засобів: ліцензування, реєстрацію в Україні, сертифікацію якості у виробника та входять до переліку зареєстрованих лікарських засобів, які вносяться до державного реєстру лікарських засобів України. 3 метою розвитку інноваційних технологій запроваджено 
диференційований контроль якості лікарських засобів, що ввозяться для реалізації, та контроль якості препаратів, що ввозяться для інших цілей. Наприклад, для проведення доклінічних і клінічних випробувань, реєстрації в Україні, експонування на виставках без права реалізації, індивідуального використання громадянами та в разі стихійного лиха, катастроф, епідемій (рис. 1).

Порядок ввезення лікарських засобів через митний кордон України визначаеться Законом Україн «Про лікарські засо6 ш»

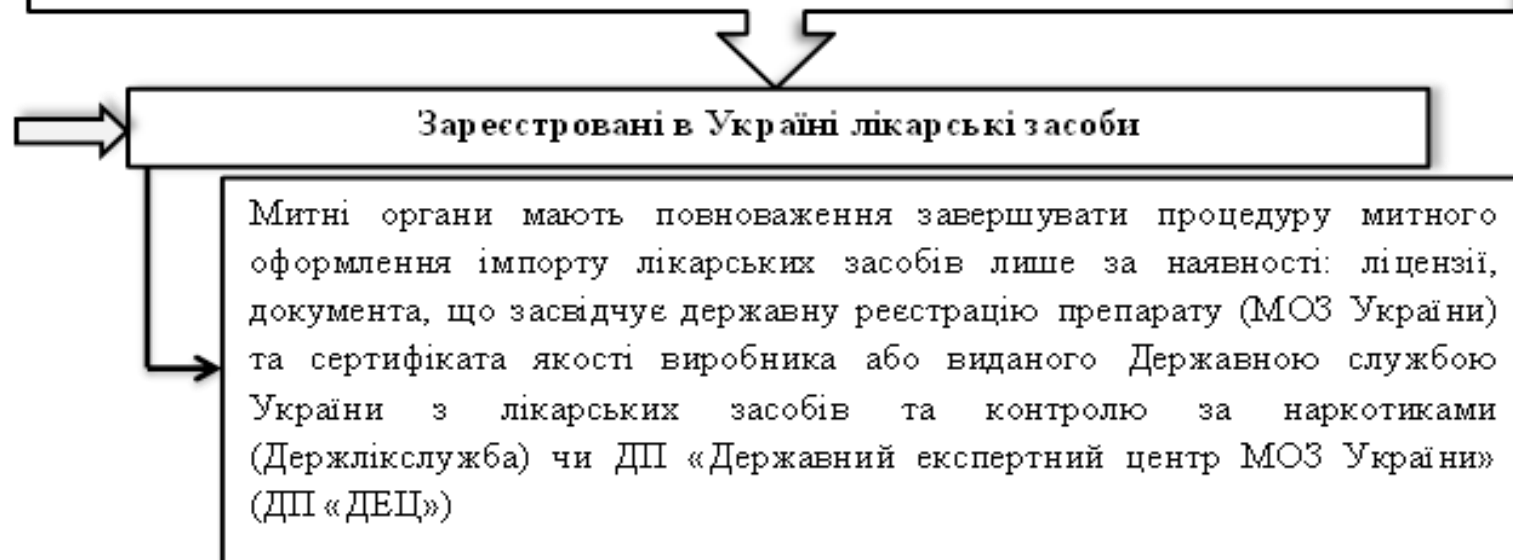

\begin{tabular}{|c|}
\hline Нез ар есс тров ані в Україні лікар ські з асоби \\
\hline $\begin{array}{l}\text { Можуть вв озитися на мптну територію України для: } \\
\text { - проведення доклінічних досліджень і клі нічних випробувань }\end{array}$ \\
\hline $\begin{array}{l}\text { - реєстрації лікарських засобів в Україні (зразки препаратів у лікарських } \\
\text { формах) }\end{array}$ \\
\hline $\begin{array}{l}\text { - експонування на виставках, ярмарках, конференціях тощо без права } \\
\text { реалізації }\end{array}$ \\
\hline - індиві дуального використання громадянами \\
\hline $\begin{array}{c}\text { Гуманіт арна допомога або певні обст авинш (стихійне лпхо, катастрофа } \\
\text { тощо) }\end{array}$ \\
\hline $\begin{array}{l}\text { медична техніка та вироби медичного призначення, що не зареєстровані в } \\
\text { Україні, можуть ввозитися на митну територію України } 3 \text { метою } \\
\text { застосування в медичній практиці лише після проведення державної } \\
\text { експертизи іхньої якості та безпеки (Держлікслуж6а, ДП «ДЕЦу) }\end{array}$ \\
\hline
\end{tabular}

Рис. 1. Порядок імпорту лікарських засобів в Україні

Визначено вичерпний перелік обставин, за яких незареєстровані лікарські засоби можуть ввозитись на митну територію України без права реалізації для: 
- проведення доклінічних досліджень і клінічних випробувань;

- реєстрації лікарських засобів в Україні;

- експонування на виставках, ярмарках, конференціях тощо;

- індивідуального використання громадянами;

тощо за окремим рішенням Міністерства охорони здоров’я України за наявності документів, що підтверджують їх реєстрацію і використання в країнах, звідки ввозяться препарати.

Порядок ввезення лікарських засобів у таких випадках визначається в наказі Міністерства охорони здоров’я України «Про порядок ввезення на територію України незареєстрованих лікарських засобів» [5].

19 червня 2016 року набули чинності зміни до Закону, згідно яких запроваджена спрощена процедура реєстрації лікарських засобів, які зареєстровані компетентними органами Сполучених Штатів Америки, Швейцарії, Японії, Австралії, Канади, Європейського Союзу.

Під якістю лікарських засобів i виробів медичного призначення розуміють їх відповідність всім умовам реєстрації та виробництва (технологія, виробничі площі, кадри) і заданим характеристикам.

При виході продукції на ринок підприємство видає сертифікат якості або відповідності, підписаний уповноваженою особою виробника, якщо воно відповідає якісним показникам реєстраційного досьє з безпеки, ефективності та вироблено відповідно до правил GMP.

До основних показників, що визначає якість фармацевтичних та медичних товарів, відносяться:

- безпека - найважливіша властивість якості, якою повинні володіти всі споживчі товари. Втрата функціонального або соціального призначення, перевищення допустимого рівня показників безпеки переводить продукцію в категорію небезпечної, яка підлягає знищенню;

- функціональні властивості - придатність продукції виконувати свої функції за призначенням в заданих умовах експлуатації або споживання;

- надійність - здатність товарів зберігати функціональне призначення в процесі зберігання та / або споживання (експлуатації) протягом заздалегідь обумовлених термінів. Вона постійно змінюється внаслідок процесів, що відбуваються при зберіганні, споживанні та експлуатації товарів.

- екологічність - ступінь шкідливого впливу медичних товарів на безпеку навколишнього середовища при їх виробництві, зберіганні та всього терміну споживання. 
Висока якість медичних i фармацевтичних товарів забезпечується контролем якості вихідної сировини, метрологічним контролем обладнання, кваліфікацією робітників і залишковим контролем якості готової продукції, розробкою вимог до умов зберігання та реалізації з подальшим контролем за дотриманням цих вимог.

В роботі проведено товарознавчий аналіз досліджуваних препаратів: визначено правильність оформлення супровідної документації; проведено аналіз асортиментної приналежності замовленого товару; встановлено відповідність товару класу, групі, виду або різновиду, вказаному в супровідній документації; проведено ідентифікацію товару за показниками «Опис», «Маркування», «Пакування». За результатами проведеного аналізу невідповідностей не виявлено.

3 метою недопущення обігу фальсифікованих, неякісних та незареєстрованих лікарських засобів упроваджено механізм державного контролю за якістю лікарських засобів, що ввозяться в Україну [11].

Згідно з Митним Кодексом України митний контроль - це «сукупність заходів, що здійснюються митними органами в межах своєї компетенції 3 метою забезпечення дотримання норм цього Кодексу, законів та інших нормативно-правових актів з питань митної справи, міжнародних договорів України» (п.15 ст.1 МК України) [3]. Основні завдання митного контролю, які зумовлені його загальною метою та відповідають встановленій державою компетенції митних органів: захист економічних інтересів держави; виявлення відповідності проведених митних дій та операцій чинному законодавству; дотримання фізичними та юридичними особами встановлених митних процедур і правил при переміщенні товарів через митний кордон $[6,7]$.

Залежно від правового режиму об'єкта митного контролю С.I. Пахомов виділяє 3 види митного контролю - звичайний, спрощений і спеціальний [6]. Більш влучною вбачається наведена А.В. Мазуром класифікація митного контролю з урахуванням класифікаційних підстав, згідно з якою він виділив певні види митного контролю.

Види, форми й методи митного контролю в процесі їх практичного застосування тісно взаємопов'язані між собою. Проведений аналіз літературних джерел дозволив побудувати класифікацію видів митного контролю (МК) лікарських засобів (ЛЗ), що переміщуються через митний кордон України, наведену на (рис. 2).

Слід зазначити, що перспективним напрямком щодо вдосконалення застосування форм та методів митного контролю лікарських засобів, що 
переміщуються через митний кордон України, є мінімізація суб’єктивних чинників прийняття управлінського рішення в процесі митного контролю за рахунок об'єктивних.

Розглянуті форми митного контролю лікарських засобів, що переміщуються через митний кордон України, дозволяють митним органам точно й у повному обсязі виконувати покладені на них завдання, зокрема, захищати економічні інтереси України, контролювати дотримання іiі законодавства при переміщенні таких засобів через митний кордон. Посадові особи митного органу вправі оперувати однією формою контролю або декількома в комплексі, виходячи з доцільності їх використання.

Митне законодавство окреслює не тільки форми, а й методи митного контролю, віддаючи перевагу найбільш демократичному - вибірковому. Митний інспектор обирає такий метод, який, з його погляду, є достатнім для забезпечення перевірки заявлених фізичною чи юридичною особою відомостей про переміщувані через митний кордон лікарські засоби.

У процесі митного контролю і митного оформлення лікарських засобів 3 у разі необхідності метою застосування спеціальних знань можна залучати фахівців та експертів для участі у здійсненні митного контролю. У разі проведення експертизи лікарських засобів при порушеннях митних правил посадова особа митного органу має право брати проби та зразки товарів для дослідження (аналізу, експертизи).

Експертні організації, незалежно від форм власності (державні, кооперативні) повинні мати статус юридичної особи. Одними із таких експертних організацій є ДП «Державний експертний центр Міністерства охорони здоров'я України» (далі - ДП «ДЕЦ»), який є спеціалізованою митною установою, і митні лабораторії регіональних митниць (МЛ РМ) як структурні підрозділи митниць. Цим лабораторіям надано право на здійснення експертної діяльності, а саме безпосереднє проведення лабораторного контролю в митних цілях. Для проведення експертних досліджень лікарських засобів, у тому числі наркотичних, психотропних речовин і прекурсорів, митні лабораторії володіють сучасними аналітичними приладами, на яких можна виконувати спектр фізико-хімічних дослідів [12]. 
Товарознавчий вісник. - 2020. - Випуск 13.

Класифікація вцдів митного контр олю лікар ських засобів (ЛЗ), щ о пер еміщуються через мптнпй кордон Укр аїнг

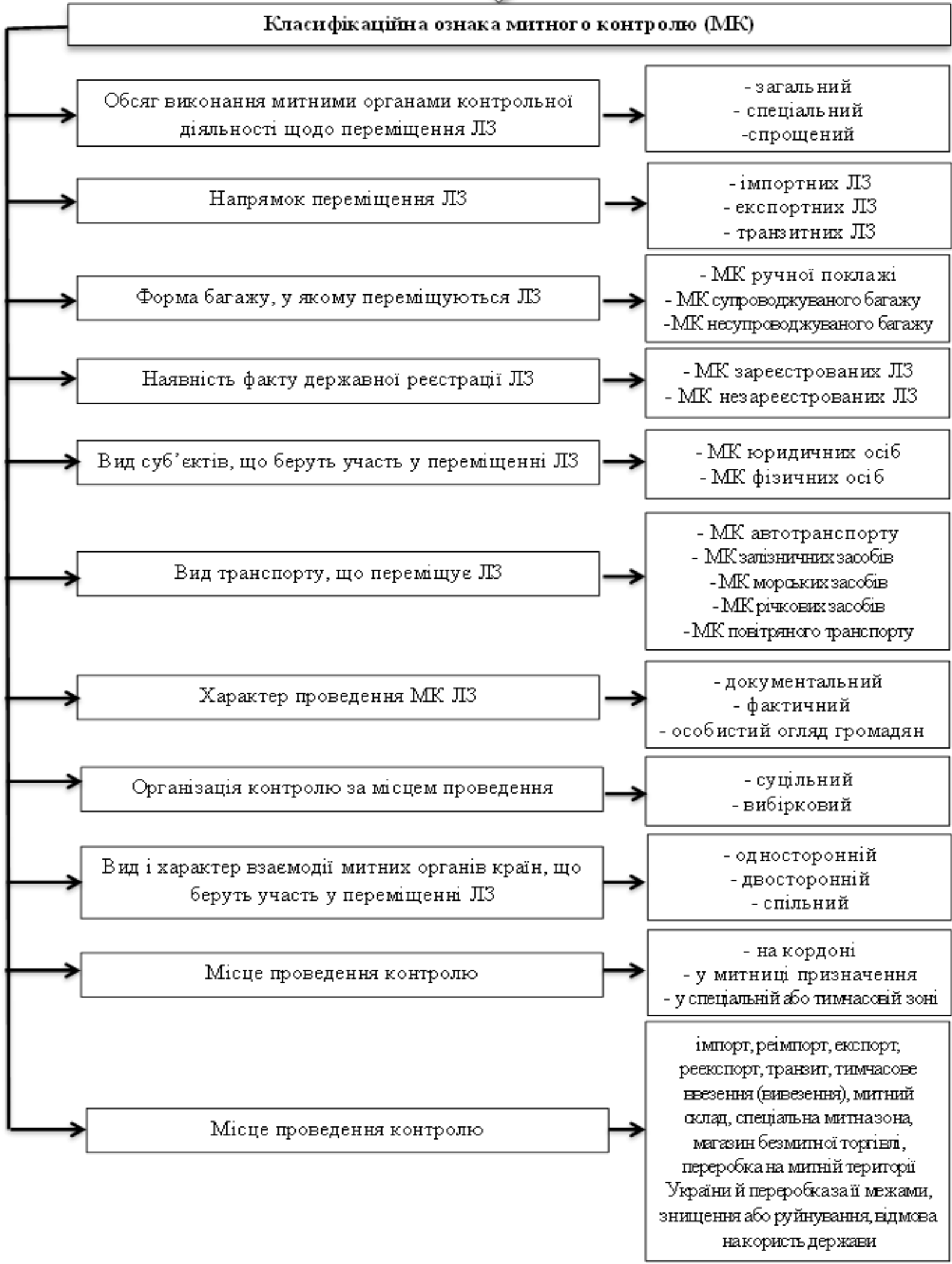

Рис. 2. Класифікація видів митного контролю лікарських засобів 
Проби та зразки товарів забираються у мінімальній кількості, що забезпечує можливість їх дослідити (провести аналіз, експертизу) за нормативами, затвердженими спеціально уповноваженим центральним органом виконавчої влади в галузі митної справи $[4,12]$.

Орієнтовна схема митної експертизи лікарських засобів при переміщенні їх через митний кордон України:

1) підготовка запитів митних органів до митної лабораторії;

2) підготовка пакету документів на об’єкт дослідження;

3) відбір проб і зразків товарів митними органами;

4) направлення зразків товару та документації до митної лабораторії;

5) проведення досліджень ДП «ДЕЦ» або МЛ РМ;

6) підготовка експертом митної лабораторії висновків за результатами досліджень;

7) направлення висновку митної лабораторії за результатами експертизи.

Від ефективності митного контролю та оформлення залежить не лише швидкість і безперебійність доступу до ліків населення України, в компетенції митних органів запобігання необгрунтованому завищенню цін на лікарські засоби. Тому митні органи приділяють особливу увагу правильності визначення таких показників, як країна походження і митна вартість, у тому числі лікарських засобів, що не включені в Державний реєстр лікарських засобів, i, серед іншого, вживаються заходи щодо прискорення митного контролю та митного оформлення лікарських засобів та виробів медичного призначення.

Висновки та перспективи подальших досліджень. За результатами досліджень встановлено, що лікарські засоби обмежені в переміщенні через митний кордон, однак обмеження не $є$ загальним, а по-різному діє на різні підгрупи фармацевтичного товару. Митні режими можуть встановлювати різні правила для переміщення різних груп лікарських засобів через митний кордон. Побудовано класифікацію видів митного контролю лікарських засобів, що переміщуються через митний кордон України.

Визначено, що імпорт лікарських засобів для реалізації в Україну може здійснюватися лише за наявності ліцензії на такий імпорт, свідоцтва про реєстрацію в Україні та сертифіката якості. Всі досліджувані лікарські засоби провідних фірм Словенії, Німеччини та Італії мали вищезазначені документи. Товарознавчий аналіз цих препаратів не виявив невідповідностей у правильності оформлення супровідної документації, аналізі асортиментної 
приналежності та ідентифікації товару за показниками «Опис», «Маркування», «Пакування».

В подальших дослідженнях планується більш детально розглянути питання щодо проведення митної експертизи лікарських засобів оскільки вона $\epsilon$ важливою ланкою їх митного контролю та митного оформлення.

\section{Список використаних джерел}

1. Рішення Рахункової палати України від 06.03.2018 p., № 4-6. 64 с. URL: http://www.ac-rada.gov.ua/doccatalog/document/16756087/Zvit_4- 6_2018.pdf?subportal=main.

2. Митич С.П. Злочини, що вчиняються у сфері виготовлення та обігу лікарських засобів в Україні: кримінологічна характеристика, детермінація та запобігання: дис. ... к-та юрид. наук: спец. 12.00 .08 «Кримінальне право та кримінологія; кримінальне право» / Митич Сергій Павлович. К., 2019. 258 с.

3. Митний кодекс України від 13.03.2012 р. Відом. Верховн. Ради Украӥни. 2012. № 44-48. Ст. 288; Ст. 552.

4. Про лікарські засоби: Закон України від 04.04.1996 р. № 123/96.Відом. Верховн. Ради Украӥни. 1996. № 22. Ст. 86, Ст. 288.

5. Про затвердження порядку ввезення на територію України незареєстрованих лікарських засобів, стандартних зразків, реагентів: Наказ Міністерства охорони здоров'я України від 26.04.2011 № 237. Офіиійн. вісн. України. 2011. № 63. Ст. 2508. С. 24.

6. Шишка Р.Б., Сергієнко В.В. Митне право України: навч. посіб. Харків: Еспада, 2002. $296 \mathrm{c}$.

7. Гаращук В.М. Митний контроль в Україні: шляхи становлення й розвитку. Пробл. законності. 2004. Вип. 66. С. 97-103.

8. Держмитслужба України зацікавлена в обміні інформацією з колегами з CC. URL: http://eunews.unian.net/ukr/detail/193971

9. Проблема якості та безпеки лікарських засобів. URL: http://www.aptekagal.com.ua/show_article.

10. Шевчук О.М. Контроль та нагляд за переміщенням лікарських засобів через митний кордон України: [монографія. Х.: Право, 2014. 272 с.

11. Shevchuk O.M. Customs control of drugs: concepts, form, methods, types and their classification. URL: http://www.stattionline.org.ua/pravo/76/12273-mitnij-kontrol-likarskixzasobiv-ponyattya-formi-metodi-vidi-ta-yih-klasifikaciya.html

12. Додін Є.В. Особливості проведення експертизи 3 деяких видів митних справ. Митна справа. 2004. № 3. С. 3-9.

\section{References}

1. Decision of the Accounting Chamber of Ukraine dated 06.03.2018, № 4-6. 64 p. URL: http://www.ac-rada.gov.ua/doccatalog/document/16756087/Zvit_4- 6_2018.pdf?subportal=main. 
2. Mytych S. P. Crimes Committed in the Sphere of Production and Circulation of Medicines in Ukraine: Criminological Characteristic, Determination and Prevention Thesis for the Candidate Degree in Law. Speciality 12.00.08 «Criminal Law and Criminology; Criminal and Executive Law». - State Research Institute of the Ministry of Internal Affairs of Ukraine; State Research Institute of the Ministry of Internal Affairs of Ukraine, Kyiv, 2019. 258 p.

3. Customs Code of Ukraine dated 13.03.2012. Vidom. Supreme Council of Ukraine. 2012. № 44-48. Art. 288; Art. 552.

4. On Medicines: Law of Ukraine of 04.04.1996, No. 123/96 // Vid. Supreme Council of Ukraine. 1996. № 22. Art. 86, Art. 288.

5. On Approval of the Procedure of Importing Unregistered Medicines, Standard Samples, Reagents into the Territory of Ukraine: Order of the Ministry of Health of Ukraine No. 237 of 26.04.2011 // Official. hanging Of Ukraine. 2011. № 63. Art. 2508. P. 24.

6. Shishka R.B. (2002). Customs law of Ukraine: study. tool. Kharkiv: Espada,.

7. Garashchuk V.M. (2004). Customs control in Ukraine: ways of formation and Probl. legality. -Vip. 66. P. 97-103.

8. The State Customs Service of Ukraine is interested in exchanging information with EU counterparts. URL: http://eunews.unian.net/ukr/detail/193971

9. The problem of quality and safety of medicines. URL: http://www.aptekagal.com.ua/show_article.

10. Shevchuk O.M. (2014). Control and supervision over the movement of medicines across the customs border of Ukraine. Kharkiv: Law.

11. Shevchuk O.M. Customs control of drugs: concepts, form, methods, types and their classification. URL: http://www.stattionline.org.ua/pravo/76/12273-mitnij-kontrol-likarskixzasobiv-ponyattya-formi-metodi-vidi-ta-yih-klasifikaciya.html

12. Dodin E.V. (2004). Peculiarities of Expertise in Some Types of Customs. Customs. №3. P. 3-9.

Цель. Исследование особенностей проведения таможенной экспертизы лекарственных средств как составной части таможенного контроля и таможенного оформления при перемещении этого вида товаров через таможенную гранииу Украины.

Методы исследования. $B$ ходе исследования использованы общенаучные $u$ специальные методы научного познания: анализ, синтез, компаративно-правовой, системно-структурный, статистический.

Результаты. Импорт лекарственных средств в Украине ограничен. Он может осуществляться только при наличии лицензии на такой импорт. Причем импортироваться могут только лекарственные средства, зарегистрированные в Украине, кроме этого, необходимо, чтобы они прошли сертификацию качества у производителя.

С иелью развития инновационных технологий введен дифференцированный контроль качества лекарственных средств, ввозимых для реализации, и контроль качества препаратов, ввозимых для других ичелей. Например, для проведения клинических испьтаний, регистрации, экспонирования на выставках без права реализации, индивидуального использования гражданами и в случае, катастроф и эпидемий. 
В работе исследована продукция 4-х иностранных фирм-производителей, лекарственные средства которых, широко представлены на фармацевтическом рынке Украины: KRKA Group, Словения; Bayer, Biologische Heilmittel Heel GmbH, Германия; JANSSEN-CILAG S.p.A. JOHNSON \& JOHNSON, Италия. По результатам проведенных товароведческих исследований вылвлено, что все исследуемые лекарственные средства вымеприведенных фирм-производителей прошли необходимые для импортируемых лекарственных средств этапы: лицензирование, регистраџию в Украине, сертификаиию качества у производителя и входят в перечень зарегистрированных лекарственных средств Украины. Также проверена правильность оформления сопроводительной документации; проведен анализ ассортиментной принадлежности указанных товаров; установлено соответствие товара классу, группе, виду и разновидности, указанных в сопроводительной документаџии; проведена идентификаџия товара по показателям «Описание», «Маркировка», «Упаковка».

Рассмотрень формы таможенного контроля лекарственных средств, перемещаемых через таможенную границу Украины и построена классификация видов таможенного контроля.

Научная новизна. Комплексное исследование современных проблем таможенного контроля $u$ экспертизы импортируемых лекарственных средств: построена классификачия видов таможенного контроля лекарственных средств, предложено провести минимизацию субъективных факторов принятия решения.

Практическая значимость. Результаты можно использовать в научноисследовательской работе для дальнейшего изучения особенностей организации таможенного регулирования внешнеэкономической деятельности; в учебном процессе при подготовке курса лекций по товароведению в таможенном деле, таможенного контроля и экспертизы товаров.

Ключевые слова: лекарственные средства, товар, таможенная граница, таможенная експертиза, таможенный контроль, таможенное оформление.

Purpose. Investigation of the peculiarities of customs examination of medicinal products as a component of customs control and customs clearance when moving this type of goods across the customs border of Ukraine.

Methodology. The research used general scientific and special methods of scientific knowledge: analysis, synthesis, comparative law, system-structural, statistical.

Findings. Imports of medicines to Ukraine are limited. It can only be carried out with a license for such imports. Moreover, only medicinal products registered in Ukraine can be imported, in addition, they must be certified by the manufacturer.

In order to develop innovative technologies, differentiated quality control of imported medicines for sale and quality control of imported medicines for other purposes have been introduced. For example, for conducting clinical trials, registering, presentation at exhibitions without the right of sale, individual use by citizens and in the event of catastrophes and epidemics.

The paper considers the products of 4 foreign manufacturers, whose medicinal products are widely represented on the pharmaceutical market of Ukraine: KRKA Group, Slovenia; Bayer, Biologische Heilmittel Heel GmbH, Germany; JANSSEN-CILAG S.p.A. JOHNSON \& JOHNSON, 
Italy. According to the results of the commodity research, it was found that all the investigational medicinal products of the above-mentioned manufacturing companies have passed the necessary stages for imported medicines: licensing, registration in Ukraine, manufacturer quality certification and included in the list of registered medicines of Ukraine. The correctness of accompanying documentation was also determined; the analysis of the assortment of the goods ordered; the conformity of the goods of the class, group, species or variety specified in the accompanying documentation is established; the identification of the goods by the indicators «Description», «Marking», «Packaging».

The forms of customs control of medicines moving across the customs border of Ukraine are considered and the classification of types of their customs control is made.

Originality. Comprehensive research of customs control current problems and examination of imported medicines: classification of types of customs control of medicines is made, minimization of subjective factors of decision making is proposed.(nроводиться - проведено класифікацію)

The practical value. The results can be used in research work to further study the features of the organization of customs regulation of foreign economic activity; in the educational process in the preparation of a course of lectures on commodity in customs, customs control and expertise of goods.

Key words: medicines, goods, customs border, expertise customs, customs control, customs clearance.

Стаття рекомендована до публікаџії доктором технічних наук, професором кафедри товарознавства сертифікації та стандартизаиії Херсонського національного технічного університету Тіхосовою Г.А. Стаття надійшла в редакиію 14.12.2019 р. 